\title{
DISTINCTION BETWEEN EUTHANASIA AND VALID MEDICAL DECISION AND ITS IMPACT ON UNBORN LIFE
}

\author{
Rihards Poḷaks \\ University of Latvia, Faculty of Law \\ Raina Blvd. 19, Riga, LV-1586, Latvia \\ Telephone: (+371) 67208892 \\ E-mail: rpolaks@inbox.lv \\ Valentija Liholaja \\ University of Latvia, Faculty of Law \\ Raina Blvd. 19, Riga, LV-1586, Latvia \\ Telephone: (+371) 67034552 \\ E-mail: liholaja@inbox.lv \\ Received on 13 February 2014, accepted on 18 March 2014 \\ doi:10.13165/JUR-14-21-1-11
}

\section{Introduction}

Nowadays, the term euthanasia is applied to those cases when a physician, consciously out of compassion with his/her action or its omission causes, promotes or does not prevent the death of an incurably ill person or upon the person's or his/ her legal representatives' request or without the consent of the above mentioned persons, with the purpose to relieve him/her from excruciating pain and suffering or from a medically unjustified extension of life. Even though the definition gives a list of detailed activities or their omission included in the understanding of the notion

Jurisprudencija/Jurisprudence

(C) Mykolo Romerio universitetas, 2014

(C) Mykolas Romeris University, 2014
ISSN 1392-6195 (print), ISSN 2029-2058 (online) http://www.mruni.eu/lt/mokslo_darbai/jurisprudencija/ http://www.mruni.eu/en/mokslo_darbai/jurisprudencija/ 
easy death, still erroneus application of certain valid medical decisions made, such as the termination of the artificial life-sustaining measures upon patients being in a persistent coma or vegetative state, as well as the termination of the applicability of terminal sedation for pain and suffering caused by an incurable disease, etc., to the cases of euthanasia in the scientific doctrine, such as medicine, law as well as others, thus distorting its understanding by obtaining the regulation that criminal liability is stipulated for the performance of euthanasia in the majority of countries around the world, exposing the legitimate activities of physicians to undergo unjustified criminal judgement.

As euthanasia and valid medical decision can also pertain to yet an unborn life in cases when a pregnant woman is exposed to termination of premature vital capacity or artificial life-sustaining measures because of incurable disease, the article addresses the issue, which has not been widely researched in the doctrine - that of the legal status of a foetus as well as the rights and possibilities to be born under conditions when there is the necessity either to consider the interests of a mother to be relieved from excruciating pain and suffering, terminating her life, or to decide on the usefulness of further artificial life sustaining measures.

In the light of the above mentioned, the aim of the article is to find out the fundamental features to be considered as to within the scope of intensive care of incurably ill persons, the valid medical decisions made, could be distinguished from the cases of euthanasia, and to find out how they impact the rights of an unborn life and its prospects to be born.

To achieve the aim of the research, analytical, systemic, comparative, inductive, deductive and logical scientific research methods were used in the course of studying medicine, biomedicine as well as foreign legal doctrine and practices.

\section{Brain death as a criterion for the end of life and its impact on the subject of debate-euthanasia}

Life ceases along with the occurrence of death or, in other words, on the grounds of irreversible cessation of cellular biological processes and the degradation of proteins ${ }^{1}$, the process, which is of gradual character, and that is the reason why brain death and biological death are distinguished in contemporary medicine.

The historical background of the criteria of the end of life states that already in ancient times the opinion of death referred to as not only the loss of the ability to live, but also the cessation of one's existence, which can be caused by the failure of lungs, brain or heart function, the latter of which is considered the essence of

1 Nāve. Populārā medicīnas enciklopēdija. Rīga: Galvenā enciklopēdiju redakcija, 1984, p. 343. 
life - the key organ, which functions first and dies last ${ }^{2}$, as it was shared by Greek physicians. Such approach to determine human death, relating it to the cessation of cardiac and respiratory function, lasted until the middle of the 20th century, when the life-sustaining medical devices advanced rapidly, allowing to prolong the human life.

As medical technologies developed and transplantation advanced, which, in turn, sought the necessity for intact and functional organs of the deceased, the way to the development of new criteria for determining death in medicine was paved ${ }^{3}$. The Ad Hoc Committee of the Harvard Medical School published the criteria for determining death in 1968, suggesting that the irreversible state of coma shall be referred to at the moment when the cessation of brain function is diagnosed. Four criteria for the determination were proposed: 1 ) unreceptivity and unresponsitivity to external stimuli; 2) lack of movement and breathing; 3 ) lack of reflexes without gaining approval of the brain function and 4) lack of brain electrical activity, which the medical devices have registered without any changes also during a revised checkup after 24 hours.

To start with, such criteria were established on the basis of improved reanimation and life-supporting measures, which have enabled to maintain the lives of patients, who are in a desperate condition. Despite the fact that the heart continues functioning, however, the brain is irreversibly damaged. Such patients suffering from constant loss of intellect are a burden, which shall be carried by the families or hospitals. Secondly, it was indicated that previous criteria of death caused arguments in respect of obtaining necessary organ transplants ${ }^{5}$. The aforementioned criteria were adopted in the 22nd World Medicine Assembly in August 1986 and included in WMA Declaration of Sydney on the Determination of Death and the Recovery of Organs ${ }^{6}$.

2 Pernick, M.S. Back from the Grave: Recurring Controversies over Defining and Diagnosing Death in History. Death: Beyond Whole - Brain Criteria. Dordrecht, Boston, London: Kluwer Academic Publishers, 1998, p. 18-19.

3 More detailed: Shah, S.K.; Miller, F.K. Can We Handle the Truth? Legal Fictions in the Determination of Death. American Journal of Law \& Medicine. 2010, 36(4): 541; Capron, A.M.; Kass, L.R. A Statutory Definition of the Standarts for Determining Human Death: An Appraisal and a Proposal. Death, Dying and Euthanasia. Washington: University Publications of America, Inc., 1977, p. 40-41.

4 A Definition of Irreversible Coma: Report of the Ad Hoc Commitee of the Harvard Medical School to Examine the Definition of Brain Death. Journal of the American Medical Association. 1968, 205(6): 337-338.

$5 \quad$ Ibid., p. 337.

6 WMA Declaration of Sydney on the Determination of Death and the Recovery of Organs. Adopted by the $22^{\text {nd }}$ World Medical Assembly, Sydney, Australia, August 1968 and amended by the $35^{\text {th }}$ World Medical Assembly, Venice, Italy, October 1983 and the $57^{\text {th }}$ WMA General Assembly, Pilanesberg, South Africa, October 2006 [interactive]. [accessed on 10-02-2014]. $<$ http://www.wma.net/en/30publications/10policies/d2/ $>$. 
A medical definition brain death is recognized as of human death and is accepted in the USA ${ }^{7}$ and many European countries ${ }^{8}$, inter alia the Republic of Latvia. The Regulations No. 215 of the Cabinet of Ministers "Order on brain death diagnosis and biological death and passing of the deceased for interment" dated 27 March 2007 indicates that brain death is a state of deep unconsciousness, which is characterized by a complete and irreversible failure of brain function, which can be concluded if the cardiac and respiratory functions are maintained by carrying out reanimation measures or intensive care and in cases when the aforementioned symptoms are diagnosed. It also accounts for the biological death as an irreversible loss of life functions of the organism, which cannot be prevented by means of reanimation techniques or intensive care".

The concept of brain death is not unanimously accepted and several times it has undergone the criticism of medical and ethical nature, e.g., neurologist Alan Shewmon holds a view that the concept of brain death, which is based on brain functions, is essentially wrong because the brain does not outweigh other organs as many processes function regardless of the brain function and the human organism is not dead until the blood flow stops irreversibly ${ }^{10}$. Douglas N. Walton also questions the sufficient arguments for the established brain death criteria, leaving space for discussions in respect of the possibility of maintaining life functions ${ }^{11}$, once emphasizing that there shall be a strict distinction between determining death and interests of transplantation, thus preventing decision making in the cases when the patient is a potential donor ${ }^{12}$.

The issue of detection of the human death at the moment of brain death shall be discussed both from the medical point of view and from the ethical and juridical aspects with a special regard to usage of organs and tissues in medicine, as the options of biological function maintenance without brain function also cause a dilemma. On the one hand, the life in a human organism still persists albeit the respiratory function

7 See: Keely, G.C., et al. Uniform Determination of Death Act. National Conference of Commissioners on Uniform State Laws, 1980 [interactive]. [accessed on 10-02-2014]. <http:// www.uniformlaws.org/shared/docs/determination\%20of\%20death/udda80.pdf>.

8 Chau, P-L.; Herring, J. The Meaning of Death. Death Rites and Rights. Oxford and Portland, Oregon, 2007, p. 17.

9 Kārtība, kādā veicama smadzeņu un biologiskās nāves fakta konstatēšana un miruša cilvēka nodošana apbedīšanai. Latvijas Vēstnesis. 2007, Nr. 59.

10 Bernat, J.L. The Biophilosophical Basis of Whole - Brain Death. Bioethics. England: Cambridge University Press, 2002, p. 327.

11 Walton, D.N. Brain Death. Ethical Considerations. West Lafayette, Indiana: Purdue University, 1980 , p. 2.

12 Walton, D.N. On Defining Death. An Analytic Study of the Concept of Death in Philosophy and Medical Ethics. Monreal: McGill-Queen's University Press, 1979, p. 5. See also: Olsena, S. Miruša cilvēka aizsardzība un audu izmantošana medicīnā. Promocijas darbs. Rīga: Latvijas Universitāte, 2010, p. 193-194. 
being maintained artificially and no signs of brain function prevail; however, it is considered that the death of a human being and biological individual has occurred due to the irreversible death of the brain - an organ, which induces the function of the organism's physiological system ${ }^{13}$.

However, from the authors' point of view, brain death within the scope of euthanasia shall be regarded in a wider sense, as it is the question of when life ends and the being is no longer defined as a human being who has the subjective right to life. In respect to this, recognition that the brain is the critical system of the organism, the loss of which disables the organism to function, is of great significance. Furthermore, the brain is not replaceable; therefore, the possibility to transplant it is halted, as well as medical stimulation devices cannot be applied for making it function ${ }^{14}$.

Brain death is recognised as a person's death; however, thanks to contemporary reanimation techniques, his/her vegetative existence form can be maintained, i.e., at a cellular level. Siluyanova (Силуянова), for instance, calls it a prolongation of dying or the zone of instability, which goes beyond the scope of ethic assumptions of a human being, as well as death and the Commandment "Thou shalt not kill" carries no meaning ${ }^{15}$. According to Goldenring ${ }^{16}$, $\mathrm{Kluge}^{17}$, Sile (Sile) $)^{18}$, the patients affected by brain death or an irreversible state of coma or being in the condition alike are not regarded as independent individuals, they do not represent a human being, which thus cancels the right to life, and the society in turn is not obliged to protect them.

In the light of the aforementioned, a conclusion shall be drawn that in every individual case of brain death there is no prevailing possibility to refer to a person in terms of Homo sapiens and the processes occurring in the body after that are solely and exclusively cellular biological processes rapidly moving toward ones demise.

The activities performed by physicians in such case in the Republic of Latvia are stipulated in the Latvian Medical Code of Ethics ${ }^{19}$ Section 2 , paragraph 10: "If the lethal case is acknowledged, the final decision regarding the projections and further treatment tactics is made by the ad hoc council of physicians", which, in accordance

13 Krylova, N., Safonov, V. K. K voprosu ob opredeleniji momenta okonchanija zhizni v ugolovnom prave Rossijskoj Federaciji. [The Issue of Determining the End-of-life Moment in the Criminal Law of the Russian Federation]. Ugolovnoje pravo. 2010, (3): 55.

14 Bernat, J. L. The Biophilosophical Basis of Whole - Brain Death. Bioethics. England: Cambridge University Press, 2002, p. 335.

15 Silujanova, I. V. Sovremennaja medicina i pravoslavije. [Contemporary Medicine and Orthodoxy]. Moskva: Moskovskoje podvorje Sviato-Troickoj Lavry, 1989, p. 27.

16 Goldenring, J. The Brain-life Theory: Towards a Consistent Biological Definition of Humanness. Journal of Medical Ethics. 1985, 11(4): 198-199.

17 Kluge, W.E.H. The Ethics of Deliberate Death. London: Kennika Press, 1981, p. 89.

18 Sīle, V. Medicinas ètikas pamatprincipi. Rīga: Izdevniecība "Zinātne”, 1999, p. 79.

19 Latvijas ārstu ètikas kodekss. Ar grozījumiem, kas izdarīti 1998.gada 9.oktobrī [interactive]. [accessed on 10-02-2014]. <http://www.arstubiedriba.lv/images/etikaskodekss.pdf>. 
with the Medical Treatment Law ${ }^{20}$ Section 1, paragraph 6, is the discussion among no fewer than three physicians, including anesthesiologist-reanimatologist's decision making on the discontinuation of the artificial life-sustaining medical devices.

It is noteworthy to emphasize that in the cases of brain death the ad hoc council of physicians does not make decisions on life or death of the patient; instead, it discusses whether further artificial sustaining of life function is efficient and ethical, as well. It indicates that it is necessary to differentiate the patient who expresses the will to end his/her life, thus relieving him/herself from suffering, from the patient who is provided with the fundamental functions of organism with the medical devices attached, and the organism is kept alive even though the brain is already dead. These particular cases are not considered euthanasia but valid medical procedure, when, as a rule, by having obtained a consent to the family members before physicians terminate useless activities.

The discontinuation of life-sustaining medical devices upon the patient who is ascertained brain death is acknowledged as valid medical procedure in many countries, e.g., Medical Confederation of the Argentine Republic Code of Ethics ${ }^{21}$ Article 134 and the Medical Agency of Chile Code of Ethics ${ }^{22}$ Article 134 stipulates that in the case of brain death of a patient, the physician has no ethical obligation to use approaches, medication or medical devices, the use of which shall prolong the current state of the patient. In Spain, in the context of euthanasia, it is acknowledged that in these cases human life does not exist, which can be destroyed ${ }^{23}$.

There are some examples, which are opposite. In Kenya, the physician is authorized to perform discontinuation of life-sustaining medical devices only when the cardiac function has terminated, since the patient, who is diagnosed to be brain dead, yet his cardiac function still continues, is declared to be alive pursuant to the law $^{24}$. In contrary to the opinion adopted by European judicial system, some scientists from Asian countries, such as Japan and South Korea, strongly oppose that the moment of brain death does not yet mean occurrence of death of human being, as it is claimed by Chong, stating that at the stage of brain death, a human can be a

20 Ārstniecíbas likums. Latvijas Vēstnesis. 1997, Nr. 167.

21 Código de Ética. Confederación Médica de la República Argentina [interactive]. [accessed on 21-07-2013]. <http://comra.org.ar/assets/images/cms/244137d29d571505be194a4573ae33cb. $\mathrm{pdf}>$.

22 Código de Ética. Colegio Médico de Chile. A.G. Santiago de Chile, 2011 [interactive]. [accessed on 10-02-2014]. <http://www.colegiomedico.cl/Portals/0/files/etica/120111codigo_de_etica. pdf $>$.

23 Munoz, N.P. Euthanasia in the Spanish Legal System. Euthanasia in International and Comparative Perspective. The Netherlands: Wolf Legal Publishers (WLP), 2006, p. 243.

24 Wasunna, A. End-of-Life Decision Making in Kenya. End-of-Life Decision Making. A CrossNational Study. Cambridge, Massachusetts, London, England: The MIT Press, 2005, p. 138. 
victim of homicide, for the criterion of the death has not been proved yet ${ }^{25}$. The USA literature sources suggest that brain death is included in the judicial definition and the individual can be sentenced for homicide, regardless of the time period the victim has been in the state of being brain dead ${ }^{26}$. As a matter of fact, the issue of brain death is not the sole subject of debate within the scope of euthanasia. At present, quite often other valid medical procedures are erroneously related to termination of life out of compassion, which will be discussed in the next sections of the article.

\section{Failure to administer medical treatment upon individuals being in a coma - euthanasia or valid medical procedure}

Likewise in the cases of brain death, one of the wrong assumptions is to relate the non-voluntary euthanasia to individuals being in coma. Many foreign authors also support such opinion, e.g., Agnes van der Heide ${ }^{27}$, Emily Jackson ${ }^{28}$, Dabral Anupam ${ }^{29}$. The core argument to object to this statement is that the target of euthanasia is to relieve an incurably ill individual from excruciating pain and suffering induced by an illness. However, in terms of medicine, the definition of coma (from Greek, koma means "deep sleep") means a state of insensibility, which resembles a deep sleep, and the patient cannot be awoken with the help of external stimuli ${ }^{30}$. Not only the disorders of respiratory functions and circulatory system, but also absence of reflexes and failure of reaction to external stimuli, such as sound, light, pain, etc., are

25 See: Kavaguchi, H. Ugolovno-pravovyje problemy transplantaciji organov v Japoniji (Referat). [Legal Drawbacks for Transplantation of Organs in Japan (A Report)]. Sovremennoje medicinskoje pravo $v$ Rossiji i za rubezhom. Sbornik nauchnykh trudov. [Contemporary Medical Law in Russia and Abroad. Collection of Scholarlies]. Moskva: INION RAN, 2003, p. 309-310; Chong Kh.-M. Pomoshch v smerti i ugolovnoje pravo: jevtanazija v prave Juzhnoj Koreji (referat) [Help in Dying and Criminal Law: Euthanasia in the Legislation of West Corea (A Report)]. Sovremennoje medicinskoje pravo $v$ Rossiji i za rubezhom. Sbornik nauchnykh trudov [Contemporary Medical Law in Russia and Abroad. Collection of Scholarlies]. Moskva: INION RAN, 2003, p. 404-405.

26 See: Fischer, C.; Kaplan, O.C. Medical USMLE. Medical Ethics. New York: Kaplan Publishing, 2009, p. 39.

27 Heide, A. Physician Assistance in Dying Without an Explicit Request by the Patient. PhysicianAssisted Death in Perspective. Assessing the Dutch Experience. United States of America: Cambridge University Press, 2012, p. 137.

28 Jackson, E.; Keown, J. Debating Euthanasia. Oxford and Portland, Oregon: Hart Publishing, 2012, p. 2.

29 Dabral, A. Dying with Dignity. A Legal, Religious and Political Insight into the Issue of Euthanasia. Civil \& Military Law Journal. 2010, 46(3): 236.

30 Margaret, A., et al. The Gale Encyclopedia of Medicine. Second edition. Volume 2 C-F. Detroit, New York, San Diego, San Francisco, Boston, New Haven, Conn., Waterville, Maine, London, Munich: Gale Group Thomson Learning, 2002, p. 866. 
observed $^{31}$. Even though the clinical praxis does not exclude the likeliness that the individuals being in a coma partly have the ability to feel, these are, however, very rare occasions and they presume the contrary. Thus, pain cannot be acknowledged as conscious. Within the scope of medical as well as law sciences, the individuals in a coma cannot be regarded as the ones exposed to excruciating pain and suffering, irrespectively they are or are not incurably ill.

A conclusion can be drawn that euthanasia cannot be related to comatose patients since suffering, which should be felt, does not prevail or it cannot be classified as unbearable without the possibility to ease, as it is approved in foreign literature sources ${ }^{32}$. It should be added that if the cessation of the individual's life being in a coma is prompted by a physician, basing on the pilot approaches stated in the theory and practice of medicine and the final decision made by ad hoc council of physicians acknowledging that further sustainability of life is useless, such activities shall be qualified as a valid medical procedure under particular clinical conditions. Similar legal assessment is applied to those decisions, regarding the patients being in a persistent vegetative state and their care provided by physicians, which is discussed in the next section.

\section{Persistent vegetative state - precluding condition of euthanasia}

The subject of discussion hereof is the admissibility of termination of treatment of those patients, who are in a persistent vegetative state and an obvious inefficiency of treatment is observed since their consciousness is irreversibly lost as a result of patients' brain damage, except the brain stem, which still functions $s^{33}$.

On the condition that the life-sustaining medical devices just imitate the signs of life of a patient diagnosed brain dead, when the individual practically is already dead, the brain stem of the human being in a persistent vegetative state enables to maintain organism functions, such as heart rate, breathing, deglutition, thus showing evidence that the ability of the organism to live is quite autonomous. The use of artificial life-sustaining medical devices is, in turn, related to the complications faced while undergoing a medical treatment, e.g., the organism cannot provide itself with enough food, liquid, breathing, etc. It should be notably emphasized that even though the patients being in a persistent vegetative state do not have consciousness ${ }^{34}$, the irregularity of the electroencephalogram (EEG) axis is common, i.e., the function of

$31 \quad$ Ibid.

32 Legemaate, J. Classification and Definitions. Dutch Developments. Physician-Assisted Death in Perspective. Assessing the Dutch Experience. United States of America: Cambridge University Press, 2012, p. 31.

33 Brāzma, G. Bioētika. Cilvēka dzīvības radīšana un pārtraukšana. Jelgava: LLU, 2010, p. 96.

34 Chau, P-L.; Herring, J. The Meaning of Death. Death Rites and Rights. Oxford and Portland, Oregon, 2007, p. 15. 
the brain is registered, which depends on the localisation and the extent of damages ${ }^{35}$, thus, it is impossible to acknowledge them being dead in terms of de facto and de jure.

Disagreements do not occur in the cases when a patient has advanced directives for medical decisions in such situations, and with respect to their autonomy, the termination of medical treatment is required. Whereas, legally ambiguous assessment pertains to those cases when the patient's true will is unknown; however, further health care from the physician's or patient representatives' point of view is inefficient and/or excruciating for the patient.

It is questionable whether in the cases of termination of treatment by not obtaining a request from the individual, the passive non-voluntary euthanasia should be the subject of debate, taking into consideration the fact that the person being in a persistent vegetative state contrary to comatose patients and those certified as braindead usually react either on pain or other external stimuli. Noteworthy is the fact that the character of a vegetative state is expressed by reacting to pain stimuli, instinctively, not at the level of consciousness. There is no reason to qualify for euthanasia if there is a lack of consciousness of pain and suffering, as it was previously stated. That is why in all those cases, when the treatment of a patient being in a persistent vegetative state is terminated, the activity of the performer shall be regarded either as a valid medical procedure, or an offence against one's life, and it shall be judged from the aspect of the criminal law. Nonetheless, the discussions are intensified due to not only the cessation of treatment or non-initiation of the treatment of incurably ill patients of certain categories, but, within the scope of euthanasia, a great significance is paid to the legitimacy of the use of such medical means and methods, which, when adapted intentionally, foster or cause patient's death.

\section{Distinguishing criteria of deep and continuous palliative sedation as well as life-shortening drugs from euthanasia}

Nowadays, there is a wide range of palliative medications, which can be applied for sedation and control of pain and other incurable disease-related symptoms. Yet, the usage of them along with a successful result can cause side effects, which might be related to the shortening of the patient's life and in some cases even cause his/her death $^{36}$. Taking into consideration the fact that the choice between the prescription of a particular medication or withdrawal of its usage has become a common medical decision practice, especially by treating terminally ill patients, only the patient's

35 Cranford, R.E. Brain Death and the Persistent Vegetative State. Legal and Ethical Aspects of Treating Critically and Terminally Ill Patients. Ann Arbor, Michigan, Washington, D.C.: AUPHA Press, 1982, p. 72.

36 More detailed: Sumner, L.W. Assisted Death. A Study in Ethics and Law. New York: Oxford University Press, 2011, p. 49; Otlowski, M. Voluntary Euthanasia and the Common Law. New York: Clarendon Press, 1997, p. 139. 
physician is authorised to make such subjective decision, which, as a rule, is related to the so-called principle of double-effect.

According to the doctrine of double-effect, the physicians who foresee a success in terms of relieving the patient from pain and use sedatives for this purpose to such extent, which simultaneously can shorten the patient's life or cause death, cannot be accused of homicide just because they also predict the worst possible consequences the death of a patient ${ }^{37}$. The issue is still topical concerning the assessment of the activities by acknowledging them as acceptable or as an active form of euthanasia.

In the course of time, when there was not a strict demarcation line at the level of theory, a pseudo-euthanasia form was developed, namely indirect euthanasia, which is used to describe the cases when life is terminated on the grounds of side effects, within the framework of pain sedation or its prevention ${ }^{38}$. Supposedly, the main difference between euthanasia and pain control is the aim to be achieved. The opinion expressed in the foreign literature, on acknowledging the application of sedatives as "standard medical practice", should be agreed to, since the target of euthanasia is to relieve from suffering by causing the death of an incurably ill person, whereas the key target of treatment when sedatives are applied is to lessen suffering, but not to shorten patient's life or cause death, which is solely and exclusively an undesired side-effect ${ }^{39}$.

However, considering the dosage of medication, the possible negative sideeffects, which can be the patient's shortening of life or his/her death, are the utmost ways of incurable patients' care. Their applicability, from the authors' point of view, is possible only when the patient is in a terminal state and suffering caused by illness, which cannot be treated by intensive care approaches. As Jackson reasonably emphasizes, the physician who prescribes the deadly dosage of sedatives to the incurably ill patient, death must not be the principal end-in-itself; instead, he shall decide that in the interests of the patient palliation outweighs the interest of the continuation of life ${ }^{40}$.

Within the scope of the double-effect principle, palliative sedation shall be critically analysed in such cases, when it is deep and constantly applied, which is

37 Jackson, E.; Keown, J. Debating Euthanasia. Oxford and Portland, Oregon: Hart Publishing, 2012, p. 14.

38 Weyers, H. The Legalization of Euthanasia in the Netherlands. Revolutionary Normality. Physician-Assisted Death in Perspective. Assessing the Dutch Experience. United States of America: Cambridge University Press, 2012, p. 38.

39 Somerville, M. Death Talk. The Case against Euthanasia and Physician - Assisted Suicide. London: McGill-Queen's University Press, 2001, p. 202; Griffiths, J.; Bood, A.; Weyers, H. Euthanasia and Law in the Netherlands. Amsterdam: Amsterdam University Press, 1998, p. 162.

40 Jackson, E.; Keown, J. Debating Euthanasia. Oxford and Portland, Oregon: Hart Publishing, 2012, p. 15. 
also sometimes called terminal sedation, when the state of unconsciousness is caused upon a patient till the moment death occurs, declaring that its major aim is the patient's relieve from pain and suffering caused by an illness, and the medication applied has caused patient's state alike coma ${ }^{41}$. The notability of the issue is indicated only by the fact that in 2009 the European Association for Palliative Care (EAPC) criticised the cases, when, in fact, euthanasia was performed under applicability of deep palliative sedation cover, when physicians deliberately increased the dosage of medication relieving the patient from suffering, but inevitably causing death, which was considered to be a display of deviation and which in theory is known as slow euthanasia. The EAPCA also established guidelines ${ }^{42}$ on ethical, medical and judicial prerogatives of sedation within the framework of palliative care by acknowledging it to be admissible medical practice provided that it is used in accordance with its aim. Yet, it is highlighted in the document that palliative sedation is the utmost remedy for pain prevention, as it is related to several potential risks to shorten the life expectancy of a patient.

Albeit the aim of deep and ceaseless sedation and euthanasia is obviously identical, i.e., to relieve an incurably ill person from excruciating pain and suffering, yet the basic difference between them persists, which thus allows to differentiate a valid medical procedure from criminal offence, which is regarded as such in most countries of the world, i.e., active voluntary or non-voluntary euthanasia in the sense that the aim of the cases of deep and continuous palliative sedation is reached when deep unconscious state of a patient is maintained, and, in turn, active voluntary or non-voluntary euthanasia leads to person's death. That is why in cases when the palliative sedation is applied only for the sake of the aim it is not acknowledged to be a ceaseless form of euthanasia, but a valid medical practice for an incurably ill person's care. A similar opinion is also stated in foreign legal doctrine, where it is considered that if the palliative sedation is applied pro rata, to gain appropriate control over pain, it cannot be compared to the termination of life ${ }^{43}$. Still, a different solution from the situations, regarding the cases analysed in the previous sections, is required, namely when valid medical decision impacts the interests of yet an unborn life, which is described in the next section.

41 Smith, S.W. End-of-Life Decisions in Medical Care: Principles and Policies for Regulating the Dying Process. New York: Cambridge University Press, 2012, p. 11.

42 Cherny, I.N.; Radbruch, L. European Association for Palliative Care (EAPC) Recommended Framework for the Use of Sedation in Palliative Care. Palliative Medicine. 2009, 23(7): 581.

43 Legemaate, J., et al. Palliative Sedation in the Netherlands: Starting Point and Contents of a National Guideline. European Journal of Health Law. 2007, 14(1): 66. 


\section{The "dignity" of foetus in the cases of termination of life or non-sustaining of an incurably ill pregnant woman}

In respect of the context of valid medical decision, even though occurring rather rarely, the starting point is topical for a human life, i.e., from the point of view of an embryo and foetus, and evaluating it with regard to the situations, when a pregnant woman is, for instance, in a coma or in a persistent vegetative state, as well as in situations, when brain death is ascertained. Moreover, the respective issue is of great importance within the scope of euthanasia, when the pregnant woman is the one initiating a premature termination of life in order to terminate the pain and suffering caused by an incurable disease. As the right to life and life as such are different categories, it is crucial to determine the life as a biological category and subjective rights to life at the moment of conception, particularly, to clarify whether a difference persists between these categories in the sense of time, which is topical when dealing with moral and legal aspects of an unborn life.

Even though the right to life is consolidated in all contemporary international human rights documents, none of them stipulates the status of an unborn child or nasciturus, the one, which will be born in the future ${ }^{44}$. The answer regarding the issue of the right to life applicable to unborn children is not found in the practice of the European Commission of Human Rights and the European Court of Human Rights, the latter of which in several judgements points out that the understanding of the beginning of life falls within the margin of appreciation of the State, since the European countries have not reached consensus on the definition of the starting point for human life $\mathrm{e}^{45}$. The European Commission of Human Rights in turn has indicated that when the consensus among the countries will be reached, the Commission will provide its assessment, as well ${ }^{46}$.

Article 93 of the Constitution of the Republic of Latvia ${ }^{47}$ declares that "Everyone's right to life is protected by law." Considering the fact that only a born and alive human being can be involved in legal relations, since the subjective rights can be applicable to a real existing subject, thus, concluding that the notion "everyone" used

44 See, for example: Smith, R.K.M. Textbook on International Human Rights. Oxford: Oxford University Press, 2005, p. 208; Dijk, V.P., et al. Theory and Practice of the European Convention on Human Rights. 4th edition. Antwerpen, Oxford: Intersentia, 2006, p. 387-388.

45 The decisions of European Court of Human Rights regarding the case: Vo v. France [GC], No. 53924/00, § 82, ECHR 2004-VIII; Tysiac v. Poland, No. 5410/03, § 74, ECHR 2007-1; Evans $v$. the United Kingdom [GC], No. 6339/05, \$ 54, ECHR 2007-I, etc. Also, having regard to the case-law of the European Court of Human Rights concerning the issue, see as well: Jacobs, F.; White, R.; Ovey, C. The European Convention on Human Rights. Oxford: Oxford University Press, 2010, p. 71, 162-165.

46 Schutter, O. International Human Rights Law. Cambridge: Cambridge University Press, 2010, p. $404-410$.

47 Latvijas Republikas Satversme. Latvijas Vēstnesis. 1993, Nr. 43. 
in state fundamental law does not stipulate unborn in this respect. Although Article 1 of the Law on Sexual and Reproductive Health ${ }^{48}$ indicates that the target of the law is to determine the legal relations in the fields of sexual and reproductive health, this legislation does not contain any concrete guidelines considering the protection of unborn life. The rights of the foetus to be born are not taken into consideration in the Republic of Latvia, as it is approved in the cases, when the legislator initiates the protection of life with means of criminal law ${ }^{49}$ at the right moment when the foetus in the end of the birth or by surgical intervention becomes a born child.

With respect to the issue of conception of a human life, it is crucial to pay attention to contemporary fundamental concepts of embryogenesis, in particular, that from the moment of fertilization, two parental gametes generate a new biological organism - zygote, which contains a new individualised programme, and the new organism is a new human individual with his/her own genetic code ${ }^{50}$. The development of a human being is a continuous process ${ }^{51}$, which is characterised by a significant feature of embryo and foetus - inborn potential, which also stipulates the potential right to life of an unborn child, which he/she possesses from the moment of conception and reaches its peak along with the vital capacity ${ }^{52}$.

Supposedly, that is why in respect to the earliest stage of human biological life or the stage of intrauterine development it would be more appropriate to regard the foetus' right to be born, not the subjective right to life, but his/her right to adequate protection from every possible illegitimate threats, thus ensuring a successful developmental process. To make this right legitimate, an appropriate legal framework is required, as in the case of the Constitution of Ireland, which, according to Article 40, section 3, clause $3^{\circ}$ from 29 December 1937, stipulates that "The state acknowledges the right to life of unborn to the same extent as of his/her mother (...)"53, while in Hungary, for example, according to the Fundamental Law Article 2, section 1 dated on 25 April 2011, the life of an embryo and foetus is the subject to be protected from the moment of conception ${ }^{54}$, as well as in other countries.

Regarding the issue of legal protection of an unborn life within the scope of the topic of the article, it is important to distinguish active voluntary euthanasia and

48 Seksuālās un reproduktīvās veselības likums. Latvijas Vēstnesis. 2002, Nr. 27.

49 Krimināllikums. Latvijas Vēstnesis. 1998, Nr. 199/200.

50 Sgrecha, E., Tambonne, V. Bioetika [Bioethics]. Moskva: Bibleisko-bogoslovskij institut Sv. Apostola Andreja, 2002, p. 154-157.

51 Mežinska, S. Biomedicīnas ètikas problēmas. Biomedicìnas ètika: teorija un prakse. Rìga: Rìgas Stradiña universitāte, 2006, p. 107.

52 Vēvere, G. Tiesības uz dzīvību: saturs un izpratne. Jurista Vārds. 2010, 45(640): 23.

53 Bunreacht na hÉireann [interactive]. [accessed on 10-02-2014]. <http://www.taoiseach.gov.ie/ attached_files/Pdf\%20files/Constitution\%20of\%20Ireland\%20\%28Irish\%29.pdf>.

54 The Fundamental Law of Hungary: Law of Hungary. 25 April 2011 [interactive]. [accessed on 1002-2014]. <http://www.kormany.hu/download/4/c3/30000/THE\%20FUNDAMENTAL\%20 LAW\%20OF\%20HUNGARY.pdf>. 
usage of such medication and/or approaches, the undesired side effect of which is related to the shortening of the life of a pregnant woman or her death from those cases, when the diagnosis of the patient is brain death, irreversible state of coma or a persistent vegetative state.

Regarding the cases of euthanasia and the principle of double-effect, it is crucial to note the particular moment, when not only the embryo, or at a later stage - the foetus, gains the legal protection, on which the admissibility of planned activities depends, but also the stage of development of the foetus and the predicted life duration of the pregnant woman shall be noted at the moment of decision making; however, in those countries, in which euthanasia is not legal, the qualification of the performer is noted.

It should be noted that ignoring the interests of an unborn child as well as ignoring the mother's interests to be relieved from suffering shall not be acceptable in the sense that in every case prior to any medical intervention, be it medication, the side effect of which is related to the shortening of the life duration of the pregnant woman, or some of the forms of euthanasia, which also directly leaves an impact on the foetus in terms of its future vital capacity, the physicians, if only the process of decision making does not happen in urgent cases, shall assess the possibilities to retain unborn life and take every possible step to achieve a particular aim. A premature Caesarean operation, for example, can be mentioned as a possible solution, unless the life and health of the pregnant woman is threatened and foetus is in such a developmental stage, that a realistic possibility of its survival also prevails outside of the mother's body, which can be compensated with the support of medical means and devices. If it is possible to postpone the use of radical medical means or euthanasia until the moment the pregnant woman carries the foetus, the moment itself can initiate an independent life outside her body, yet in such cases to avoid prolongation of unjustified suffering a special regard shall be paid to the lifespan of a foetus, which should exceed the predictable life duration of the pregnant woman and only then if a mutual consent about the applicable approach is reached among all parties involved.

A slightly different legal assessment has cases, when the mother of foetus suffers from brain death and, de facto, she is declared dead. According to Daniel Sperling, medical technologies have advanced to such a level, that the physicians have the possibility as never before to control the moment when death occurs, enabling to sustain the vital capacity of a pregnant woman, whose brain is dead, to maintain the development of foetus up to 107 days $^{55}$. Furthermore, in the 21 st century, court praxis is developing regarding this issue, the proof of which is University Health Services $v$. Piazzi case $\mathrm{C}^{56}$, when the Court of Georgia satisfied the claim of a medical institution 
not to terminate the applicability of life-sustaining medical devices upon a pregnant woman, who was ascertained brain death, until the birth of the child. Considering the possible ethics-related issues, it is supposed that at present no noticeable judicial arguments are observed for the prohibition of applicability of such practice, hence in such cases there is no legal subject present, whose rights are involved because of it. And even though contrary to the cases of brain death, the patients being in an irreversible state of coma or those being in a persistent vegetative state, as concluded previously, cannot be acknowledged dead de facto and de jure; also, their artificial sustaining of life cannot be contrary to legal and medico-ethical standards if only the pregnant woman's organism is temporary used and is justified with the foetus interests to be born on the grounds of consensus made among physicians and the representatives.

\section{Conclusions}

Nowadays, in the theory of medicine and law as well as in practice, biological death and brain death are defined and also acknowledged, considering the fact that along with the diagnosis of brain death the patient within the scope of legal science loses the designation human being, who has the subjective right to life. Therefore, the decision of the ad hoc council of physicians to terminate the measures for artificial sustaining of life, which in the end shall cause biological death, is not related to any form and kind of euthanasia, but is to be considered a valid ethical, legal and medical procedure, which is justified on the grounds of the loss of the efficiency of the above mentioned support measures further to be carried out.

Passive non-voluntary euthanasia cannot be qualified as such to persons, who are in a coma or in a persistent vegetative state. If such cessation of life has been induced by a physician, basing on the methods approved by medical theories and practice, and the verdict made by the ad hoc council of physicians, acknowledging that the further artificial sustaining of life is useless, then such cases shall be regarded as particular valid medical procedures under particular clinical conditions, since there is no prevailing pain and suffering of patients involved, which is a compulsory prerogative for the performance of any form of euthanasia upon the patient, or the pain and suffering cannot be regarded as unbearable without any possibility to ease them.

Even though the aim of the deep and continuous palliative sedation and euthanasia is identical, i.e., to relieve incurably ill person from excruciating pain and suffering, yet the way of achieving it differs radically, namely in the first case it is achieved when the state of deep unconscious state is caused well before the moment when the patient's death occurs, but in the case of euthanasia it is achieved immediately by causing a person's death. Therefore, in cases, when deep and continuous palliative sedation is applied in accordance with its aim, it is not acknowledged as a persistent 
form of euthanasia, but as a valid medical practice for the care of incurably ill persons. The example mentioned before is analogically related to the situations emerging as a consequence of the so called principle of double-effect.

In every case prior to the performance of any medical manipulation, be it medication, the undesired side-effect of which is related to the shortening of the lifespan of a pregnant woman, or some form of euthanasia, which also directly impacts the issue of the vital capacity of foetus, the physicians - unless the decision making process takes place in emergency situations - shall evaluate the possibilities of sustaining an unborn life and do their best to achieve this aim. Also, the patient's right to be relieved from pain and suffering caused by the disease should be taken into consideration. In cases, when brain death is diagnosed upon a pregnant woman, or she is in a persistent vegetative state, her artificial sustaining of life cannot be in conflict with the standards of medical ethics and legal standards, provided that the temporary usage of organism of a pregnant woman is justified due to the interests of foetus to be born by consensus made among the physicians and the patient's representatives.

\section{References}

A Definition of Irreversible Coma: Report of the Ad Hoc Commitee of the Harvard Medical School to Examine the Definition of Brain Death. Journal of the American Medical Association. 1968, 205(6): 337-338.

Ārstniecības likums. Latvijas Vēstnesis. 1997, Nr. 167.

Bernat, J.L. The Biophilosophical Basis of Whole - Brain Death. Bioethics. England: Cambridge University Press, 2002, p. 327-335.

Brāzma, G. Bioētika. Cilvēka dzīvības radī̌sana un pārtraukšana. Jelgava: LLU, 2010.

Bunreacht na hÉireann [interactive]. [accessed on 10-02-2014]. <http:// www.taoiseach.gov.ie/attached_files/ Pdf\%20files/Constitution\%20of\%20 Ireland\%20\%28Irish\%29.pdf>.

Capron, A.M.; Kass, L.R. A Statutory Definition of the Standarts for
Determining Human Death: An Appraisal and a Proposal. Death, Dying and Euthanasia. Washington: University Publications of America, Inc., 1977, p. 40-41.

Chau, P-L.; Herring, J. The Meaning of Death. Death Rites and Rights. Oxford and Portland, Oregon, 2007, p. 15-17.

Cherny, I.N.; Radbruch, L. European Association for Palliative Care (EAPC) Recommended Framework for the Use of Sedation in Palliative Care. Palliative Medicine. 2009, 23(7): 581.

Código de Ética. Confederación Médica de la República Argentina [interactive]. [accessed on 21-07-2013]. <http:// comra.org.ar/assets/images/cms/24 4137d29d571505be194a4573ae33cb. pdf $>$.

Código de Ética. Colegio Médico de Chile. A.G. Santiago de Chile, 2011 [interactive]. [accessed on 10-02- 
2014]. <http://www.colegiomedico. cl/Portals/0/files/etica/120111codigo_ de_etica.pdf $>$.

Cranford, R.E. Brain Death and the Persistent Vegetative State. Legal and Ethical Aspects of Treating Critically and Terminally Ill Patients. Ann Arbor, Michigan, Washington, D.C.: AUPHA Press, 1982, p. 72.

Chong, H.-M. Pomoshh v smerti i ugolovnoe pravo: jevtanazija $\mathrm{v}$ prave Juzhnoj Korei (Referat) [Help in Dying and Criminal Law: Euthanasia in the Legislation of West Corea (A Report)]. Sovremennoe medicinskoe pravo $v$ Rossii i za rubezhom. Sbornik nauchnyh trudov [Contemporary Medical Law in Russia and Abroad. Collection of Scholarlies]. Moskva: INION RAN, 2003, p. 404-405. Dabral, A. Dying with Dignity. A Legal, Religious and Political Insight into the Issue of Euthanasia. Civil \& Military Law Journal. 2010, 46(3): 236. Dijk, V.P., et al. Theory and Practice of the European Convention on Human Rights. 4th edition. Antwerpen, Oxford: Intersentia, 2006.

Fischer, C.; Kaplan, O.C. Medical USMLE. Medical Ethics. New York: Kaplan Publishing, 2009.

Goldenring, J. The Brain-life Theory: Towards a Consistent Biological Definition of Humanness. Journal of Medical Ethics. 1985, 11(4): 198-199.

Griffiths, J.; Bood, A.; Weyers, H. Euthanasia and Law in the Netherlands. Amsterdam: Amsterdam University Press, 1998.

Heide, A. Physician Assistance in Dying Without an Explicit Request by the Patient. Physician-Assisted Death in Perspective. Assessing the Dutch Experience. United States of America: Cambridge University Press, 2012, p. 137.

Jackson, E.; Keown, J. Debating Euthanasia. Oxford and Portland, Oregon: Hart Publishing, 2012.

Jacobs, F.; White, R.; Ovey, C. The European Convention on Human Rights. Oxford: Oxford University Press, 2010.

Kavaguchi, H. Ugolovno-pravovye problemy transplantacii organov $\mathrm{v}$ Japonii (Referat) [Legal Drawbacks for Transplantation of Organs in Japan (A Report)]. Sovremennoe medicinskoe pravo $v$ Rossii i za rubezhom. Sbornik nauchnyh trudov [Contemporary Medical Law in Russia and Abroad. Collection of Scholarlies]. Moskva: INION RAN, 2003, p. 309-310.

Kārtība, kādā veicama smadzeņu un biologiskās nāves fakta konstatēšana un miruša cilvēka nodošana apbedīšanai. Latvijas Vēstnesis. 2007, Nr. 59.

Keely, G.C., et al. Uniform Determination of Death Act. National Conference of Commissioners on Uniform State Laws, 1980 [interactive]. [accessed on 10-02-2014]. <http:// www.uniformlaws.org/shared/docs/ determination $\% 20$ of $\% 20$ death / udda80.pdf $>$.

Kluge, W.E.H. The Ethics of Deliberate Death. London: Kennika Press, 1981.

Krimināllikums. Latvijas Vēstnesis. 1998, Nr. 199/200.

Krylova, N.; Safonov, V. K voprosu ob opredelenii momenta okonchanija zhizni v ugolovnom prave Rossijskoj Federacii [The Issue of Determining the End-of-life Moment in the 
Criminal Law of the Russian Federation]. Ugolovnoe pravo. 2010, (3): 55.

Legemaate, J. Classification and Definitions. Dutch Developments. PhysicianAssisted Death in Perspective. Assessing the Dutch Experience. United States of America: Cambridge University Press, 2012, p. 31.

Legemaate, J., et al. Palliative Sedation in the Netherlands: Starting Point and Contents of a National Guideline. European Journal of Health Law. 2007, 14(1): 66.

Latvijas ārstu ètikas kodekss. Ar grozījumiem, kas izdarīti 1998.gada 9.oktobrī [interactive]. [accessed on 10-022014]. <http://www.arstubiedriba.lv/ images/etikaskodekss.pdf $>$.

Latvijas Republikas Satversme. Latvijas Vēstnesis. 1993, Nr. 43.

Margaret, A., et al. The Gale Encyclopedia of Medicine. Second edition. Volume 2 C-F. Detroit, New York, San Diego, San Francisco, Boston, New Haven, Conn., Waterville, Maine, London, Munich: Gale Group Thomson Learning, 2002.

Mežinska, S. Biomedicinas ētikas problēmas. Biomedicīnas ètika: teorija un prakse. Rīga: Rīgas Stradiṇa universitāte, 2006, p. 107.

Munoz, N.P. Euthanasia in the Spanish Legal System. Euthanasia in International and Comparative Perspective. The Netherlands: Wolf Legal Publishers (WLP), 2006, p. 243. Nāve. Populārā medicīnas enciklopēdija. Rìga: Galvenā enciklopēdiju redakcija, 1984.

Olsena, S. Miruša cilvēka aizsardzība un audu izmantošana medicīnā. Promocijas darbs. Rīga: Latvijas Universitāte, 2010.
Otlowski, M. Voluntary Euthanasia and the Common Law. New York: Clarendon Press, 1997.

Pernick, M. S. Back from the Grave: Recurring Controversies over Defining and Diagnosing Death in History. Death: Beyond Whole - Brain Criteria. Dordrecht, Boston, London: Kluwer Academic Publishers, 1998, p. 18-19.

Schutter, O. International Human Rights Law. Cambridge: Cambridge University Press, 2010.

Sgrechcha Je., Tambone V. Bioetika [Bioethics]. Moskva: Biblejskobogoslovskij institut sv. apostola Andreja, 2002.

Seksuālās un reproduktīvās veselības likums. Latvijas Vēstnesis. 2002, Nr. 27.

Shah, S. K.; Miller, F. K. Can We Handle the Truth? Legal Fictions in the Determination of Death. American Journal of Law \& Medicine. 2010, 36(4): 541 .

Silujanova, I. V. Sovremennaja medicina $i$ pravoslavie [Contemporary Medicine and Orthodoxy]. Moskva: Moskovskoe podvore Svjato-Troickoj Lavry, 1989.

Sīle, V. Medicinas ètikas pamatprincipi. Rīga: Izdevniecība "Zinātne”, 1999.

Smith, R. K. M. Textbook on International Human Rights. Oxford: Oxford University Press, 2005.

Smith, S. W. End-of-Life Decisions in Medical Care: Principles and Policies for Regulating the Dying Process. New York: Cambridge University Press, 2012.

Somerville, M. Death Talk. The Case against Euthanasia and Physician - Assisted Suicide. London: McGillQueen's University Press, 2001.

Sperling, D. Maternal Brain Death. American Journal of Law \& Medicine. 2004, 30(4): 454. 
Sumner, L.W. Assisted Death. A Study in Ethics and Law. New York: Oxford University Press, 2011.

The Fundamental Law of Hungary: Law of Hungary. 25 April 2011 [interactive]. [accessed on 10-022014]. <http://www.kormany.hu/ download/4/c3/30000/THE\%20 FUNDAMENTAL\%20LA W\%20 OF\%20HUNGARY.pdf $>$.

Tysiac v. Poland, No. 5410/03, § 74, ECHR 2007-1.

University Health Services v. Piazzi, No. CV86-RCCV-464. Cited: Sperling, D. Maternal Brain Death. American Journal of Law \& Medicine. 2004, 30(4): 494.

Vēvere, G. Tiesības uz dzìvību: saturs un izpratne. Jurista Vārds. 2010, 45(640): 23.

Vo v. France [GC], No. 53924/00, $₫ 82$, ECHR 2004-VIII.

Walton, D.N. Brain Death. Ethical Considerations. West Lafayette, Indiana: Purdue University, 1980.

Walton, D.N. On Defining Death. An Analytic Study of the Concept of Death in Philosophy and Medical Ethics. Monreal: McGill-Queen's University Press, 1979.
Wasunna, A. End-of-Life Decision Making in Kenya. End-of-Life Decision Making. A Cross-National Study. Cambridge, Massachusetts, London, England: The MIT Press, 2005, p. 138.

Weyers, $H$. The Legalization of Euthanasia in the Netherlands. Revolutionary Normality. PhysicianAssisted Death in Perspective. Assessing the Dutch Experience. United States of America: Cambridge University Press, 2012, p. 38.

WMA Declaration of Sydney on the Determination of Death and the Recovery of Organs. Adopted by the $22^{\text {nd }}$ World Medical Assembly, Sydney, Australia, August 1968 and amended by the $35^{\text {th }}$ World Medical Assembly, Venice, Italy, October 1983 and the $57^{\text {th }}$ WMA General Assembly, Pilanesberg, South Africa, October 2006 [interactive]. [accessed on 1002-2014]. <http://www.wma.net/ en/30publications/10policies/d2/>.

\title{
EUTANAZIJOS ATSKYRIMAS NUO TEISĖTO MEDICININIO SPRENDIMO IR JO POVEIKIS NEGIMUSIAI GYVYBEI
}

\author{
Rihards Poḷaks, Valentija Liholaja \\ Latvijos universitetas, Latvija
}

Anotacija. Straipsnyje analizuojama eutanazijos ir teisètu medicininiu sprendimu, kuriuos priima medikai, rūpindamiesi nepagydomai sergančiais ligoniais, takoskyra. Kadangi analizuojant atskiras eutanazijos formas pastebimos analogijos su medicinos procedūromis, pavyzdžiui, gyvybès funkcijas palaikančių aparatų atjungi- 
mas pacientams, kuriems konstatuota smegenu mirtis ar kurie yra vegetacinès būklès ir pan., straipsnyje analizuojami dažniausi atvejai, kai mediku sprendimas ir kaip jo rezultatas atlikti veiksmai ar neveikimas sukelia poreikị aiškintis tokio sprendimo teisètuma, atskiriant ji nuo baudžiamujų veiku, kuriomis tokio pobūdžio veiksmai yra laikomi daugelyje pasaulio valstybiu.. Kadangi praktikoje kiekvienas tokio tipo sprendimas gali turèti itakos negimusiai gyvybei, straipsnyje taip pat analizuojamos vaisiaus teisès ir galimybès gimti tokiomis aplinkybèmis, kai besilaukiančios moters gyvybei gresia pavojus dèl nepagydomos ligos.

Reikšminiai žodžiai: aktyvi savanoriška eutanazija, aktyvi ir pasyvi nesavanoriška eutanazija, terminaline sedacija, smegeny mirtis, dvigubo poveikio principas, nuolatinè vegetaciné būklè, negimusios gyvybès teisiné apsauga.

\title{
DISTINCTION BETWEEN EUTHANASIA AND VALID MEDICAL DECISION AND ITS IMPACT ON UNBORN LIFE
}

\author{
Rihards Polaks, Valentija Liholaja \\ University of Latvia, Latvia
}

Summary. The article is dedicated to revealing those aspects which allow to distinguish euthanasia from valid medical decisions which are made by physicians within the scope of the care of incurably ill persons and their impact on the issue regarding yet unborn life. As in separate forms of euthanasia and the realisation of its kinds, analogies of valid medical procedure are observed, the article analyses the most common cases when the decision made by the physician and the resultant action or omission of the action binds him/her to unjustified criminal judgement by revealing the fundamental features which approve the legitimacy of the decision made, thus distinguishing it from the criminal offence, which is considered to be in most countries around the world, i.e. euthanasia.

Within the scope of research, it is concluded that nowadays passive non-voluntary euthanasia cannot be applied to the cases when artificial life-sustaining measures are terminated upon the patients who are diagnosed brain dead, coma or a persistent vegetative state, as in all these cases a compulsory prerogative of performance for every form of euthanasia and its kinds is missing, i.e. excruciating pain and sufferings caused by incurable disease, which a patient shall not only feel, but also realise. However, a different judicial assessment is regarded to such applicability of medical aids or methods, the undesired side-effect of which is related to shortening of lifespan or even death of a patient, which results from the "double-effect principle". In such cases, valid medical 
procedure can be talked about if separate applicability of medication or enhancing of the dosage, or deep and continuous palliative sedation is based on the necessity to release incurably ill person from pain and sufferings caused by disease not to cause his/ her death and only then when under concrete clinical conditions it cannot be done by other sources or approaches.

Considering that the cases analysed in the article can affect yet unborn life, in every such situation prior performing any medical manipulation, in the result of which death of an incurably ill pregnant woman will or can occur, physicians shall assess the possibilities of sustaining the unborn life and do their best to reach this aim.

Keywords: active voluntary euthanasia, active and passive non-voluntary euthanasia, brain death, "principle of double-effect", terminal sedation, persistent vegetative state, legal protection of an unborn life.

Rihards Poḷaks, Latvijos universiteto Teisės fakulteto doktorantas. Mokslinių tyrimų kryptys: baudžiamoji teisè, bioteisè.

Rihards Poḷaks, University of Latvia, Faculty of Law, PhD student. Research fields: criminal law, biolaw.

Valentija Liholaja, teisès mokslų daktarè, Latvijos universiteto Teisès fakulteto Baudžiamosios teisès katedros vedèja, profesorè. Mokslinių tyrimų kryptys: baudžiamoji teisè, bioteisè.

Valentija Liholaja, University of Latvia, Faculty of Law, Head of Department of Criminal Law, Dr. iur., Prof. Research fields: criminal law, biolaw. 